\section{Marginalisation and Multifunctional Land Use in Hungary ${ }^{1}$}

\author{
Gábor Szabó $^{1}$ - Alajos Fehér ${ }^{2}$ \\ University of Debrecen, Centre for Agricultural Sciences, \\ ${ }^{1}$ Faculty of Agricultural Economics and Rural Development, \\ Department of Agricultural and General Economics, Debrecen \\ szabog@helios.date.hu \\ ${ }^{2}$ Research Institute, Karcag \\ regiocon@axelero.hu
}

\section{SUMMARY}

Our study prepared as a brief version of National Report in the frame of EUROLAN Programme. We deal with the interpretation of some definitions (marginalisation of land use, multifunctionality of land use, marginalisation of agriculture, multifunctionality of agriculture), with sorting and reviewing indicators of marginalisation and finally with the analysis of functions of land use. We suggested a dynamic and a static approach of marginalisation. We can explore the dynamic process by time series and the static (regional) one by cross-section analyses.

It is very hard to explain the perspective of the future of marginalisation of land and of agriculture in Hungary. The process of marginalisation seems faster in the agriculture in the coming years, but it depends on the utilisation of new possibilities given by the EU financial resources and by the Common Market. At this moment agriculture seems one of the big losers of the accession.

In the long term we should face considerable challenges in the land use. It is necessary to take into account that there is a supply market of foods and traditional fibre production world-wide. There are limited possibilities to produce and to market for example biodiesel (fuel), bioethanol, or maybe biogas. Thus the environment and landscape preservation becomes more and more real land use alternatives.

The environmental interpretation of the multifunctionality of land use: activities (functions) of environmental preservation and nature conservation in a certain area, which aim to preserve natural resources by the existing socio-economic conditions.

Preservation of rural landscapes is the task mainly for landusers, who can be commanded by legal means and can be encouraged by economic measures to carry out the above activity. In the recent past measures of „command and control” type regulation were predominant, however nowadays, especially in the developed countries, the role of economic incentives increases.

As a conclusion of our analysis we can state that as long as the main land-dependent activities (agriculture, forestry, housing, tourism, local mining) cease to be viable under an existing socioeconomic structure, then it is hardly possible to sustain the rural landscape on an appropriate level by non-commodity products (such as environment preservation, cultural heritage, nature conservation, employment etc.).

\footnotetext{
1 The study was prepared in the frame of EUROLAN (EU-5 Framework Project), QLK5-CT-2002-02346, as a compiled version of the Hungarian National Report, The national project coordinator: Prof. Dr. Gabor Szabo.
}

A part of places with high ecological values coincides with the areas with unfavourable agricultural endowments and underdeveloped micro-regions. We think so that the marginalisation preserves the non-environmental-sound activities and hinders the development of multifunctional agriculture and this process can change only by joint utilisation of endogenous and exogenous resources and methods. Thus the successful programmes for agri-environmental protection and multifunctional land use can serve the moderation of negative effects of marginalisation or maybe the marginalisation process itself.

Keywords: agricultural marginalisation, land use marginalisation, multifunctional land use

\section{AGRICULTURAL AND LAND USE MARGINALISATION}

The exact definition of agricultural and land use marginalisation is not widely known in the Hungarian terminology. It is only occasionally included in special literature. Thus the terminology elaborated by the participants of EUROLAN Programme is noteworthy. Accordingly agricultural marginalisation ,is a process driven by a combination of social, economic, political and environmental factors by which in certain areas farming ceases to be viable under an existing land use and socio-economic structure and no other agricultural options are available, so the process ends at land abandonment." (Guidelines, 2003).

Marginalisation of land use, according to the said definition: ,is a process, driven by a combination of social, economic, political and environmental factors by which the use of land for the main land-dependent activities (agriculture, forestry, housing, tourism, local mining) ceases to be viable under an existing socio-economic structure." (Guidelines, 2003).

For clarifying and making the definition more widely utilisable, we suggested on one hand a dynamic and on the other hand a static approach of marginalisation. We can explore the dynamic process by time series and the static (regional) one by crosssection analyses.

The basis of process of marginalisation depends on the quantity, structure and quality of natural resources. However, socio-economic and political factors influence the process of marginalisation nowadays, by a growing extend. In this sense, social demands on agriculture are the most important although not exclusive - ones and they are only more or less reflected in the certain agricultural policy. 
There are numerous studies in international literature dealing with the changing attitude of the demand on agriculture and with the growing demand on public goods and externalities OECD and UN (2002); OECD (2001); Brower and Lowe (1998); Cahill (2001); Harte and O'Connell (2003). The readers can find some relevant Hungarian publication as well.

Baranyi (2001) thought at the of 90's that „There are numerous signs, which indicate that regional differences existing long time ago will increase, or at least preserve, and the danger of moving to the periphery threatens expending areas of the Great Hungarian Plain, regarding frontier areas, microregions and settlements as well."

The author investigated 119 cumulative less favoured frontier settlements in Eastern-Hungary (in counties of Hajdú-Bihar and Szatmár) by survey and interviews. Some main conclusions:

- the positive balance of migration is surprising, which is the result of multiple factors: constrained removal back from cities, the settlement of people coming from the other side of the border and the immigration of gypsies, which is getting stronger,

- more that $1 / 3$ of the population in active age is unemployed, which is up to a great measure in the case of gypsies,

- the significance of agriculture is very high in the field of employment and source of income,

- foreign capital is hardly present on the settlements of ,the periphery of the periphery",

- the most developed settlements of the frontierline are the ones which are in a ,specific trading position" and which have a higher number of inhabitants,

- beyond the frontier connections of local government - especially the economic ones - are not really significant,

- the impact of tourism is weak,

- local intelligence is represented almost entirely by teachers.

Fehér (2000) in his study titled: „About our cumulative less favoured areas" indicates the following factors as the causes of permanent less favoured situation:

- the population is ageing, the structure of age is unfavourable,

- atomic structure of rural settlements (villages),

- lack of employment possibilities, high unemployment rate,

- low economic performance and income level,

- low density of enterprises, weak adaptation ability, modest innovation potential,

- unfavourable endowments.

The author examines connections between unfavourable agricultural endowments and the cumulative disadvantages of regions in details. He points out, that there are different definitions exist in the agri-economic literature of settlements with unfavourable or less favourable endowments and less favoured socio-economic development.

He suggests the following points to examine the spatial structure and spatial units from the agriculture point of view:
- endowments (land quality, sloping, water management, unfavourable chemical reaction etc.) which are above the average,

- demographic and economic features (e.g. high density of agricultural population compared to natural endowments etc.) hampering adaptation ability of agricultural producers and entrepreneurs and regional innovation,

- the marginal character, e.g. it is not possible to formulate such production structure which could provide income through market prices, which could hold interest of agricultural producers for long term without special measures.

According to Enyedi: „The present process of regional inequality can be traced back to the geographical differences of human resources." $\mathrm{He}$ adds that „To be uneducated means not only less knowledge, but the lack of adaptability and learning ability as well."

He stresses furthermore, that „The development of each region depends on decisions made by economic actors and households... This is a paradox situation, that there are only a few national researches dealing with the nature of decisions determining regional development, connection between company and region and the situation of coming into existence of those decisions."

According to his opinion, „The regional development was greatly influence by sectoral lobbies. Pushing into the background of the agrarian lobby between 1990-1994 led to the situation that the most serious crisis of employment and income was taking place in Eastern-Hungary featuring rural characteristics."

Finally he concludes, „The development or underdevelopment of the economy and society is based on structural characteristics. ... The governmental regional policy should have supported...programmes organised by bottom-up activities on the first place." Enyedi (1996:122, 125, 126, 129).

Szücs et al. used mathematical- statistical methods to locate areas with unfavourable conditions in an EU-conform manner. Among other points, they stated that ,unfavourable condition in agriculture means in substance that the proportion of the land compared the population having a hard life on that, is higher than optimal ... the population still earning their living from agriculture, which is bigger than the optimal one determined by the ability of land providing for, generate more disadvantages through the disadvantage of agriculture." Szücs et al. (2001:68).

Sarudi (2003) gives a detailed description about the main important issues of Hungarian underdeveloped regions.

The criterion of marginalisation can be analysed on the basis of their characteristics on one hand and on their level on the other hand. It is practical to order indicators or group of indicators for the examination.

Among indicators accepted by the participants of EUROLAN Programme the biophysical requirements are relatively easy to gather and can be collected in a 
way that will allow international comparison and which can be shown on maps as well.

\section{Biophysical factors}

Among these factors - as the first group for elaboration of indicators of marginalisation - land supply, soil quality, configuration of the terrain are the most important ones.

Regarding the management of land in a given country, it is an important feature in what measure the country disposes over the land as a natural resource. The most comprehensive indicator of land supply is the density of population. Generally speaking, in countries where the density of population is high, they pay more attention to rational land use. The other important indicator of land supply is the proportion of agricultural land in the country's territory and the proportion of set-aside land, which are out of cultivation finally. The other indicators used are the different uses of the land area compared to the total area.

It is particularly interesting which uses of the land area the set-aside land concern and how the portion of each use of the land area changes in comparison with the total cultivated area.

The structure of arable land can be examined also, since the composition of animal husbandry can be guessed from that fact, which is in turn an important factor regarding employment. Expansion of some species of plants, e.g. sunflower, can cause problems concerning soil protection. The increase of the proportion of fallow is the most obvious evidence of marginalisation.

The measure of data on land quantity is not enough alone, since the different countries and regions are not homogeneous regarding land quality.
Soil quality, configuration of the terrain and water supply can significantly influence land productivity and the possibility of afforestation. Climate can make a huge impact on land use possibilities.

Finally, it is the function of biophysical characteristics, which resources (e.g. sand pit, gravel pit etc.) can be utilised in a certain area; even the methods of construction are influenced by biophysical characteristics.

In Hungary the physical extent (dimension) of agricultural land has only slightly decreased during last decade, since the economy of the country started to recover only in the second half of the $1990 \mathrm{~s}$, so thus relatively few ,greenfield developments" took place.

The shrinking volume of amelioration investments, the physical deterioration of irrigation capacities, the setback of use of agri-chemicals to the level of the 1960s, the use of organic fertilisers at a lower level due to the decrease in animal livestock resulted in the decrease of soil productivity, which in turn caused a reduction in average yields. Furthermore, weather conditions (drought, flood) were also unfavourable in the last decade.

The lower level of use of agri-chemicals and liquid manure was favourable from the view of environment protection and nature conservation; the process of soil acidification has stopped.

Generally speaking we can state, while it can be said that agri-ecological potentials were over-used in the 1970s and 1980s, in the last decade we did not use exploit them fully.

On the base of relevant sources we illustrate the most important aggregated endowments by maps including the soil productivity values (Figure 1) and agricultural suitability indices (Figure 2) in Hungarian macroregions.

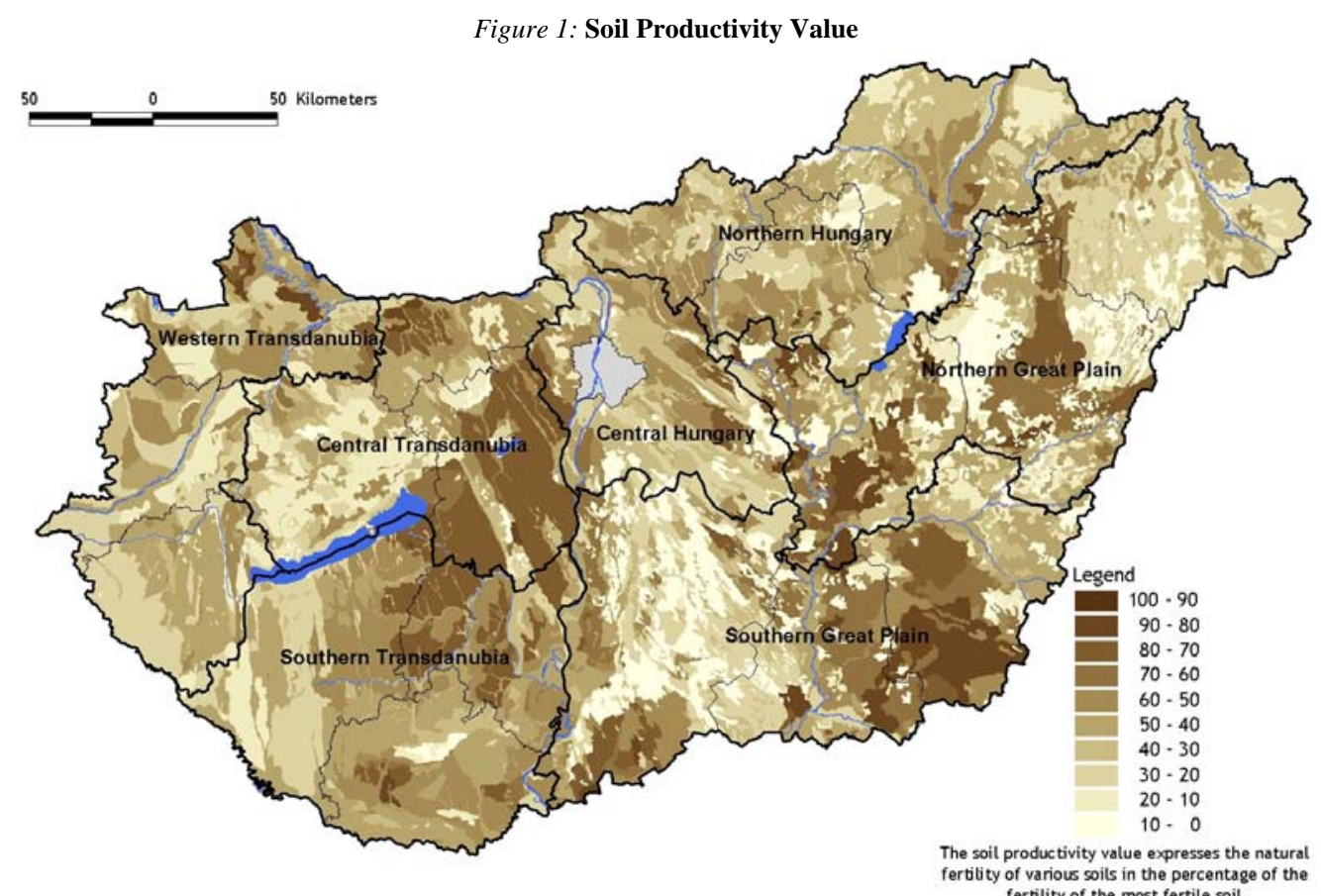

Source: Research Institute for Soil Science and Agricultural Chemistry of the Hungarian Academy of Sciences 
Figure 2: Map of Agricultural Suitability Index

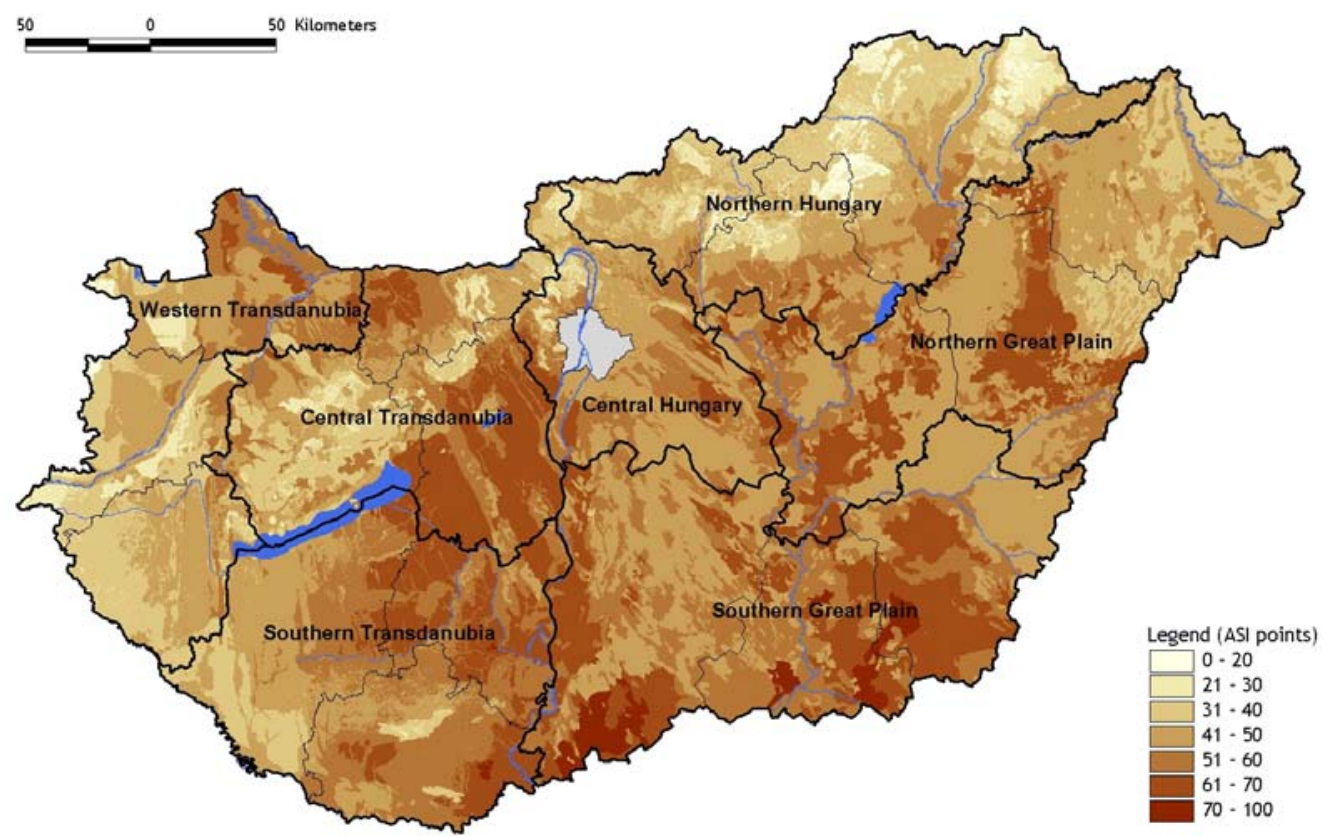

Source: Szent István University Institute of Environmental Management

Both maps demonstrate that there are considerable differences between regions in endowments of agriculture. The low soil productivity and agricultural suitability appears in contiguous areas of Northern Hungary and Western Transdanubia and in the larger part of the border areas of the country. It should also be noted that these indices are important in indicating potential marginalisation, however we mustn't overestimate their role. Marginalisation has a very wide criterion system which can be approach only by numerous and methodised indices. In this system the economic data and indicators calculated of them are inevitable.

On the other hand we would like to point out the difficulties of gathering of cost and income data. For example, GDP, which is a favoured one among economic indicators, is not accessible at micro-region (NUTS-4) level.

Likewise data of Standard Gross Margin (SGM) is not accessible at micro-region level, which would have been indispensable to calculate Economic Size Unit (ESU). In the European Union, ESU is calculated by dividing the SGM expressed in EURO by 1200 .

In the framework of Accountancy Data of Model Farms, the Research and Information Institute for Agricultural Economics collects data covering 1388 independent (private) farmers and 369 corporations (enterprises) annually. As the lowest dimension they defined 2 ESU (Keszthelyi and Kovács, 2002).

In previous years some attempts were made for elaboration of added values at the level of settlements. The basic source of the data was the database of Tax and Financial Auditing Office (Fehér, 2001).

\section{Socio-economic factors}

These factors can form the second group of indicators for marginalisation. They can be analysed both at the farm level and the regional level.

We can group the socio-economic factors at the farm level as follows:

- land-ownership and land use,

- capital accumulation,

- employment relations,

- market relations (conditions) (sale safety, ratio of input-output price indexes in agriculture etc.),

- income circumstances.

Well-arranged and stable land-ownership and land use circumstances are fundamental, and a lack of those shapes the course of marginalisation. The scattered structure of land property, which is common in eastern- and central Europe, definitely damages, and sometimes makes impossible land use. On the other hand, international experiences show that competitiveness and productivity of agricultural production is not significantly influenced by the fact, whether owned or hired farmed holdings prevail.

In modern agriculture (including forestry and fishery as well), capital accumulation is of crucial importance. Its significant and steady deterioration is the unmistakable sign of marginalisation.

The changes of level of employment in a certain economy can be measured only with regard to other employment possibilities. If the part-time and full- 
time jobs in agriculture cease to exist and rural people cannot find jobs in another sector, this can be considered as a sign of marginalisation.

Market relations (conditions) are naturally dominating in a market economy, among them we regard sale safety and changes in ratio of inputoutput price indexes in agriculture as outstanding factors.

Concerning sale safety, the organisation of farmers into co-operatives and to some other integrating organisations can lead to a favourable result. The widening gap of ratio of input-output price indexes in agriculture can be considered as a „megatrend”, organisations of integration can only restrain that.

At the farm level, the real value of income per capita and its compositors should be taken into account. If the real value of income per capita significantly and tendentiously decreases, then the farm is on the way to marginalisation. However, if the decrease of income coming from traditional agriculture can be countervailed by multifunctional activities, than we can talk about marginalisation only in a limited way. Essentially, the marginalisation of traditional agriculture takes place in that case.

At regional level, the above mentioned factors are valid as well, however the most important indicators are the following ones:

- level of infrastructure and services,

- unemployment rate,

- employment rate in agriculture,

- average quality of 1 ha arable land (in golden crown value $)^{2}$,

- income per regular inhabitants.

When unemployment rate is stagnant and high or may be increasing, that indicates the marginalisation of the area (region, county, micro region). Income per regular inhabitants and its changes in real value can show the state of marginalisation and its dynamic process of a certain area in financial terms. The level of infrastructure, especially transportation and telecommunications, can influence the above mentioned categories.

Taking into consideration that land use in every country belongs to the broader definition of agriculture (agriculture + forestry + fishing), it is possible to take into consideration the employment rate in agriculture and the average quality of 1 ha

\footnotetext{
${ }^{2}$ The ,taxable net income" of each parcel of land registered in the land cadastre was established almost a hundred years ago, in the execution of Act VII of 1875, and was later converted to Gold Crowns, the monetary unit of the Austro-Hungarian Monarchy. This valuation still serves as a basis of valuing agricultural land for the purposes. The national average of ,taxable net income” of all agricultural land is 19.16 Gold Crowns per hectare.
}

arable land as important indicators when examining the marginalisation of a certain are.

In Hungary the Parliament Resolution 24/2001 (20 April) developed a complex indicator based on 19 basic variables measuring the state of development. Among the indicators used two agricultural indices were: the proportion of agricultural employees and the "Golden Crown" value per ha, which reflects the quality of the land.

From the point of our research it is worth paying attention especially to the most undeveloped 42 micro-regions. In the cases of these micro-regions the starting point was a rank based on the complex indicator measuring development. The threshold value (2.57) was the $60 \%$ of the complex indicator of Budapest which has the highest point (4.28). The undeveloped micro-regions ranked between 2.57 and 3.36 (national average) points of the complex indicator (KSH, 2003a).

Figure 3 illustrates that 94 micro-regions have relatively low value of the indicator in question, 42 are most underdeveloped, while 52 are underdeveloped micro-regions among them.

The most undeveloped micro-regions can be found in the regions of Northern Great Plain (31\%) and Northern Hungary (29\%), but they cause serious problems in South Transdanubia (19\%) and Southern Great Plain (19\%) as well. Agricultural activity still plays an important role in employment in the above mentioned regions.

The percentage of agriculture, forestry and fishery in the GDP produced in the four regions is as follows:

$\begin{array}{lr}\text { Southern Transdanubia } & 9.9 \\ \text { Northern Great Plain } & 11.3 \\ \text { Northern Hungary } & 4.2 \\ \text { South Great Plain } & 13.0 \\ \text { while the national average is } & 5.5\end{array}$

Source: HCSO, 2003a, 2003c

The distribution of inhabitants and agricultural employees of the most underdeveloped regions is summarised in Table 1.

Henceforth we give an overview about the socioeconomic data of regions (NUTS-2), paying special attention to the most undeveloped 42 micro-regions (NUTS-4), according to the following categories:

- population, vital statistics,

- economic and social indicators,

- housing, public utility, education,

- trade, tourism, passenger cars, telephones,

- active corporations and unincorporated enterprises. 
Figure 3: Underdeveloped and most underdeveloped micro-regions (NUTS-4) in Hungary in 2002

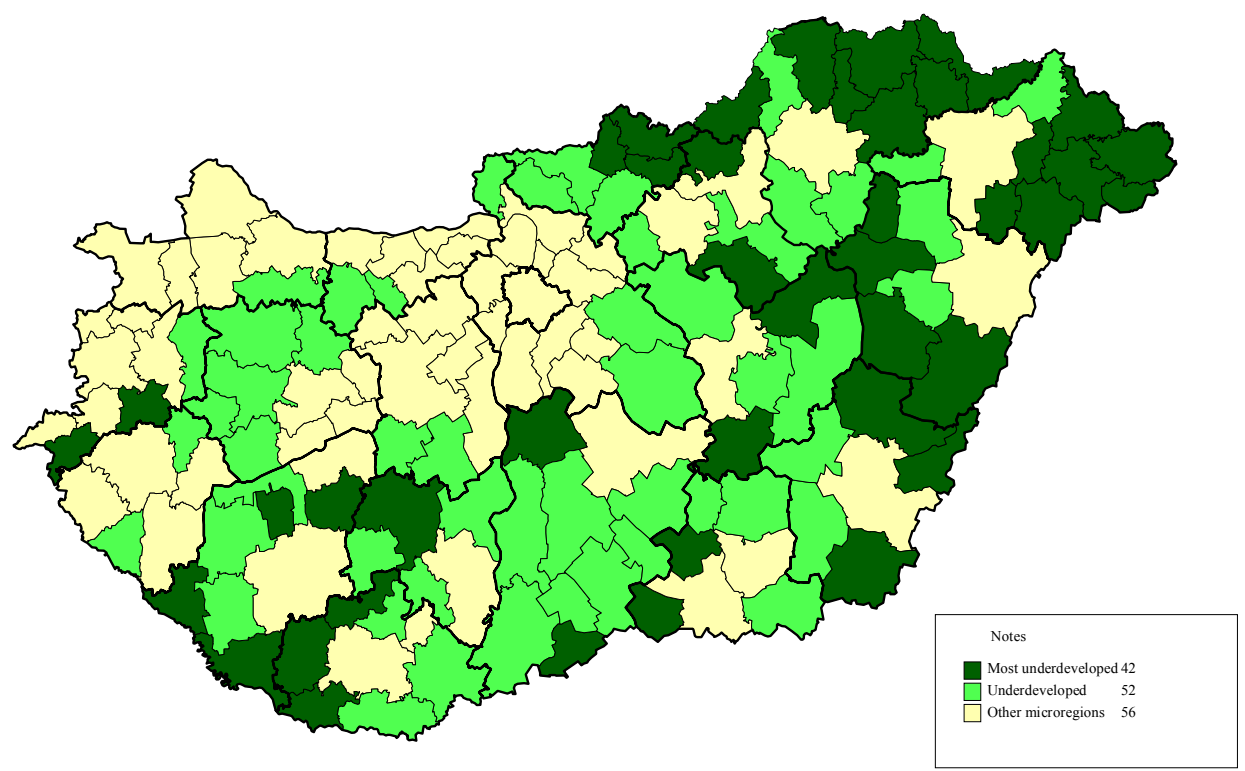

Source: KSH (Faluvégi), 2003b

Number of most undeveloped micro-regions (NUTS-4), distribution their inhabitants and share of their agricultural employees by regions (NUTS-2)

\begin{tabular}{|l|r|r|r|}
\hline \multicolumn{1}{|c|}{ Regions } & \multicolumn{1}{c|}{$\begin{array}{c}\text { Number of the most } \\
\text { undeveloped micro-regions }\end{array}$} & $\begin{array}{c}\text { Distribution of inhabitants in } \\
\text { percentage } \\
\text { (All 42 micro-regions = 100) }\end{array}$ & \multicolumn{1}{c|}{$\begin{array}{c}\text { Share of agricultural } \\
\text { employees as \% of all } \\
\text { employees }\end{array}$} \\
\hline C-H & 0 & 0 & 1.5 \\
\hline C-T & 2 & 0 & 5.2 \\
\hline W-T & 2 & 2.3 & 5.6 \\
\hline S-T & 8 & 17.7 & 8.2 \\
\hline N-H & 12 & 37.3 & 4.2 \\
\hline N-G-P & 13 & 32.9 & 7.8 \\
\hline S-G-P & 7 & 15.4 & 12.5 \\
\hline Total & $\mathbf{4 2}$ & $\mathbf{1 3 . 8}$ & $\mathbf{5 . 5}$ \\
\hline
\end{tabular}

Source: HCSO, 2003a, 2003b

\section{Population, vital statistics}

In this respect, internal net migration in the last four regions is negative, which means that the number of permanent inhabitants decreases, which is the sure sign of marginalisation. The migration is particularly significant from Northern Hungary and Northern Great Plain, in which regions can be found $60 \%$ of the most underdeveloped micro-regions.

The other striking thing is that population aged 60 and over as $\%$ of the permanent population - with the exception of Northern Great Plain - is above the national average.

We note that in the average of 42 micro-regions, the migration surplus is -1.5 , while proportion of the population aged 60 and over is equal to the national average.

\section{Economic and social indicators}

The central region (Central Hungary), as well as Central and Western Transdanubia, which are bordering on Slovakia and Austria, are much more developed according to data of GDP per capita than the other regions. In the region with the most strongly undeveloped micro-regions the Gross output per capita is $63-74 \%$ of the national average. It is necessary to underline as well that $2 / 3$ of the total agricultural Gross value added of the country is produced in the regions mentioned above.

As we have already referred, the role of agriculture is significant in these regions, in turn the unemployment rate is $30 \%$ higher than the national average.

The influencing rule of agriculture on rural viability can be seen well from the fact that in Southern Great Plain agriculture - despite of its low profitability - support subsistence for great many people. The high proportion of agricultural employees means that the unemployment rate is substantively lower in micro-regions of Southern Great Plain than in the average of the 42 microregions.

From the point of taxability, the efficiencies of underdeveloped regions are modest, yet the average of 42 micro-regions (175 EUR) is less the half of the national average $(44.8 \%)$. 
Housing, public utility, education

The number of ceased dwellings per 100 dwellings built is much higher in underdeveloped regions than in developed areas, which shows the relative deterioration of housing in the latter ones.

The proportion of dwellings connected to public sewerage is only $21.5 \%$ in the 42 most underdeveloped micro-regions and this can cause environmental problems. The lower level of education enhances the difficulties of the underdeveloped regions and micro-regions.

\section{Trade, tourism, passenger cars, telephones}

The 42 micro-regions referred above are in subordinated situation according to retailing and bedplaces. Southern Transdanubia stands out from the regions regarding its favourable numbers which is mainly due to Balaton tourism.

The number of telephone main lines per 1000 inhabitants is very low in Northern Hungary and Northern Great Plain but this disadvantage is perhaps mitigated by the use of mobile phones.

It is likely that the low number of passenger cars increases the tensions of marginalisation, especially in the regions with many most underdeveloped micro-regions.

\section{Active corporations and unincorporated enterprises}

Reviewing active corporations and unincorporated enterprises, it is most striking that the number of corporations and unincorporated enterprises per 1000 inhabitants is very low in the examined regions, with the exception of Southern Transdanubia.

We note that in agriculture (incl. forestry and fishery) 239,000 full-time employees were registered in total in Hungary in 2001. If we take into consideration full-time private farmers without taxcards as well, then in total $(239,000+25,000)$ fulltime private farmers work in the Hungarian agriculture.

However, the number of farms above holding size is almost one million (!) nowadays in Hungary, their average area is approximately 3 ha. It is worth noting together with the above ones, that with the exception of Southern Transdanubia, in the other three regions the value of agricultural investments per hectare is significantly below the national average. This is, of course, a sign of marginalisation, which also strengthens it.

\section{Human resources and rural landscape}

The third group of factors is linking with the human resources. Level of education plays important role in the above sense. A qualified workforce can adapt itself in a more flexible way to socio-economic changes and obviously can produce higher added value. Cultural heritage can make a great impact on marginalisation through business (working) culture.

The appearance of a country is fundamentally influenced by the status of rural landscapes, as the fourth group of factors to be analysed in the frame of marginalisation. Within the above - in different measures for each country - the volume and state of cultivated agricultural area and forestry are determining factors. Preserving cultivated (manmade) landscapes can be the basis of development of other branches of the economy, like tourism.

The protection of land quantity and quality especially in countries with high density of population - is of fundamental national interest.

Where land is temporary uncultivated, it is the obligation of the owner or user of the land to preserve the man-made landscape of the area (weed killing, extermination of pests, defence against erosion etc.). The use of the most productive lands in other ways than in agriculture is restricted in some countries by legal means. Soil protection is significant especially in areas facing water- and wind-erosion.

\section{The current situation of the marginalisation of agriculture in Hungary}

During the last 15-20 years Hungarian agriculture has been in a permanent crisis which is caused by the various factors. After the change of regime the main indicator of the marginalisation of agricultural land and of agriculture has been the diminished agricultural gross output. The real value of the total agricultural output at this time is about $30 \%$ less than it was at the end of the 1980s. The output of animal husbandry decreased even much more, as the livestock numbers had very heavily declined.

(Share of agriculture in the national GDP is currently $4 \%$, it was more than $15 \%$ before the change of regime.)

In the Hungarian countryside, especially in the most undeveloped micro-regions, unemployment is the most important socio-economic issue. Until the change of regime a very severe latent unemployment existed in the agricultural co-operatives and in the state farms in the 1980s and with the development of a market economy a lot of people lost their jobs in agriculture. Unfortunately the rate of unemployment does not show the real situation, so in the future we can use this indicator for studying of marginalisation only with reservations. If we subtracted the number of people of active aged are present in labour market from the number of total active aged population, a more relevant and usable indicator would be calculated.

The long-standing regional differences have rapidly increased during they last one and half decade and we are afraid that they are expected to increase more after the accession into European Union.

In Hungary marginalisation is mainly a socioeconomic issue but it can cause serious environmental problems, too.

It is sure that the agricultural area has declined in favour of forest and uncultivated lands during the last three decades and the process seems likely to be continued. The state of the agricultural land (especially concerning grassland, vineyards, orchards) is much worse than it was in the 1980s. 
It is very hard to explain the perspective of the future of marginalisation of land and of agriculture in Hungary. The process of marginalisation seems faster in the agriculture in the coming years, but it depends on the utilisation of new possibilities given by the EU financial resources.

At this moment agriculture seems one of the big losers of the accession. A political decision was made that the farmers in the new member countries will get much less money from EAGGF than the present EU farmers. It will cause terrible competitive disadvantages for the Hungarian agricultural producers. The biggest problem is that the technical and the technological levels are low in our agriculture and there is no hope of achieving a valid improvement in this field. A political decision was taken in November 2003 that the single area payment scheme (SAPS) will be used in Hungarian agriculture during next three years.

Naturally, some sectors seem to be winners: wheat, maize, oil seeds, protein plant production, beef cattle and sheep breeding. Other sectors will be losers: pig and poultry breeding, milk producers.

Some fruit, vegetable and grape producers will be able to get some gains from the new subsidy regime supposing to make good marketing and integration work in the future.

Unfortunately, it is expected that a larger part of grassland users will not get any SAPS subsidy. (Grassland covers 1 million hectares but approximately 470,000 hectares will be subsidized.) (Popp et al., 2004).

The production and farm structure of Hungarian agriculture is expected to change.

The structure of plant production will change in favour of the arable land sector which is unfavourable according to employment conditions. The pig and the poultry sectors will also suffer from very large losses which will generate unemployment problems in the countryside as well.

A large part of the small farmers will finish farming as market activity and try to find other jobs. It is a big question whether the new programmes of rural development, which are preferred by Brussels for the new member countries, will help these people to make a living or not.

It is a big mistake that the socio-economic impact analysis of the EU accession was not yet worked out.

\section{MULTIFUNCTIONAL LAND USE}

After the European Chart for Rural Areas (1995) was published, it was clear that functions of rural areas can be counted among three groups: economic, ecological and social functions.

The Chart considers it is necessary to develop „multifunctional agriculture” and it listed among the roles of agriculture beyond production the following ones:

- preservation and maintenance of the natural landscape, in a way that it is the ,capital" of tourism as well,
- preservation of rural values, lifestyles and cultural goods and some other social functions which are necessary for the community.

The Chart states about the connection of the agriculture and rural areas: ,without viable agriculture rural areas are not able to fulfil their vital tasks, which is organised in a way to be guided by requirements of rural life (e.g. in family farms) and has close connections to nature. Agriculture is the backbone of rural areas." (Ángyán et al., 1999:22).

It is evident from the above that if we could consider agriculture as the backbone of rural areas, than the marginalisation of agriculture could be disastrous.

Thus one of basic question of our research is: How the multifunctional land use can contribute to the counterbalancing of negative effect of marginalisation, especially in less favoured agricultural areas?

Mulvany (1999) writes in his Conference Report as follows:

,There are no internationally agreed definitions of the character of agriculture but the reasons to consider the multifunctional character of agriculture and related land-use in the Conference were:

- Agriculture and related land-use contribute through several its functions to fulfilling Agenda 21, Chapters 10 and 14 (sustainable agriculture and rural development and land)....

- Agriculture has the capacity to contribute in several ways to welfare. For instance, it is geographically extensive, has a direct impact on nature and the environment and provides the primary food material that ensures humankind subsistence.

- Recent trends towards a more intensive and specialised form of agriculture have successfully increased our ability to feed the word, but, in some cases, at the expense of social and/or environmental goals. In such cases agricultural policy should strive to achieve a more optimal balance between social, environmental and economic objectives.

- Nowadays, the growing attention given to the non-food functions of agriculture has augmented the relevance of policies to address the multifunctional character of agriculture and land within the framework of sustainable agriculture and rural development. In developing those policies participants confirmed the importance of targeted, transparent and cost-effective policies which do not distort production and trade. Furthermore, these policies should contribute to food security."

According to the definition accepted by the EUROLAN participants multifunctional land use means ,... the functions sustained by the land resources beyond their primary production functions (non commodity products) such as environment preservation, cultural heritage, nature conservation, employment etc.” (Guidelines, 2003). 
We suggested to supplement the above definition, since socio-economic conditions decisively determine what kind of production functions are possible by the natural resources (Szabó and Fehér, 2003).

The idea of the multifunctional agriculture and land-use is still a new one in Hungary.

Popp (2003) states: „It is more and more of importance that the agriculture beyond its primary function - food and raw material production contributes to landscape and biodiversity conservation, as well as to the social-economic sustainability of the rural society."

In the long term we should face considerable challenges in the land use. It is necessary to take into account that there is a supply market of foods and traditional fibre production world-wide. There are limited possibilities to produce and to market for example biodiesel (fuel), bioethanol, or maybe biogas. Thus the environment and landscape preservation becomes more and more real land use alternatives (Balázs et al., 2002).

The environmental interpretation of the multifunctionality of land use: activities (functions) of environmental preservation and nature conservation in a certain area, which aim to preserve natural resources by the existing socio-economic conditions.

Preservation of rural landscapes is the task mainly for land-users, who can be commanded by legal means and can be encouraged by economic measures to carry out the above activity. In the recent past measures of ,command and control” type regulation were predominant, however nowadays, especially in the developed countries, the role of economic incentives increases.

The breakthrough in the EU regarding this aspect was the 2078/92 Council regulation which was accepted in the framework of the CAP-reform in 1992. (The regulation was about the appropriate support of agricultural production, which meets the requirements of the preservation of landscape and environmental protection.)

Effective measures at present are contained by the Unified Directive for Rural Development accepted at Berlin Summit in 1999 (Official Journal, 1999).

Taking into account that users of the land impact on the landscape primarily by agricultural activity and forestry, developing the farmer's environmentally-friendly consciousness and interest is of key importance. If environmentally-friendly activity takes place in agricultural areas and in forestry, then conservation of rural landscapes is solved.

Protection of off-farm „common property areas” is the task of local, regional or governmental organisations.

It is of primary importance that farmers should receive remuneration for the losses coming from limitation of their activities and for the additional costs emerging due to their services aiming environmental protection and preservation of the landscape. We note that the interpretation of agrienvironmental externalities as exclusively agricultural output is disputed by many experts (Cahill, 2001; Harte and O'Connell, 2003).

Cahill (2001) defines externalities as follows: „externalities occur when an event, such as production of a good, confers a benefit (positive externality) or damage (negative externality) on people who themselves have not been involved in the decision leading to the benefit or the damage. Because these benefits or damages are not taken account into account in the decisions of the producers, positive externalities tend to be undersupplied and negative externalities over-supplied."

There is a positive impact on concerned actors, when it is about favourable external effects. If it concerns the farmer then his/her profit will be higher, if it makes impact on the consumer, than standard of living will increase.

While generally speaking, economics is forced to deal with negative externalities, during the examination of environmental functions of multifunctionality of land use positive externalities deserve attention.

As we have underlined above, the state of the rural landscape depends on the activity of farmers and foresters. For centuries, as unpaid by-product of their production activity they contributed gratis to the preservation of live and inanimate natural elements, cultural heritage and man-made landscape. These explicit advantages will be lost to society if the number and activity of farmers decreases below a crucial value, not to mention the case, if it will cease to exist due to the marginalisation process. Therefore, it was a change of paradigm of functions of agriculture in the European Union in the last 15 years.

The point is, that farmers through nature conservation and landscape protection activities, furthermore through preservation of cultural heritage carry out special services resulting positive externalities for smaller or bigger communities of the society. Since, these services influence effectiveness of their food and fibre production in a negative way (decrease in their income, increase of their cost), moreover these can totally secede from them (e.g. in the case of maintenance of abandoned areas), the fulfilment of services has to be remunerated morally and financially.

Farmers and foresters will play a more and more considerable role in producing and maintaining public goods. From point of view of our issue, the following items can be considered such goods:

- forests with cultural, social and protective primary aims,

- natural water resources (both surface and subsurface water resources),

- air quality,

- soil,

- raw materials (gravel, sand) for local mining,

- biodiversity of nature conversation areas,

- biodiversity of forests and meadows,

- natural caves,

- rural landscape,

- rural cultural heritage. 
Preservation of the above-mentioned public goods is only possible with a complex system of environmental policy measures. The main elements are:

- normative demands,

- colourful support system,

- social dialogue.

Examining connections among multifunctionality versus public goods and externalities, Cahill (2001) states ,Jointness is a supply-side issue.”

He states the need to examine the demand side as well. According to his opinion, the right answer can be found by answering the following questions:

- „Is the non-commodity output jointly produced with an agricultural commodity and if so, to what degree can it links with commodity production be changed, e.g. by changing farm practices or technology?"

- „Is there market failure?”

- „Have non-governmental options such as market creation or voluntary provision been explored as the most efficient strategy?"

According to Cahill (2001) the right answer can be found by consideration of social benefits and costs (direct and indirect), furthermore by the exploration of characteristics of the particular area or region.

Landscapes are very important resources of rural economies. Maintaining them is not possible without substantive agricultural activity or forestry. That means that there is a need for employment of a certain size of agricultural labour force in a certain area, in order that other types of commodity production and novel service can be carried out based on them.

Among others, Harte-O'Connell thinks that there are some cases when there is no need for connection of activities maintaining rural landscape and agricultural activities (Harte and O'Connell, 2003).

As long as the main land-dependent activities (agriculture, forestry, housing, tourism, local mining) cease to be viable under an existing socio-economic structure, then it is hardly possible to sustain the rural landscape on an appropriate level by non-commodity products (such as environment preservation, cultural heritage, nature conservation, employment etc.).

Concerning the Hungarian situation, there is only a modest development in the multifunctional use of land in our time.

After long preparation National Agrienvironmental Protection Programme started up, which include several action programmes and motivate farmers for environmental activity by landbased supports. In the frame of this programme a kind of system of zones was successfully developed, where areas important from a nature conservation point of view, and areas suitable for extensive farming which are not sensitive from nature conservation point of view, were separated from lands suitable for intensive agricultural production (Ángyán et al., 1999; Balázs et al., 2002).

The future of agriculture of those zones will depend on the fact that Brussels very ungenerously gives support for the traditional agricultural production in the case of recently accessing countries. (EU will guarantee the fraction of direct payments.) Programmes, which will not or slightly increase agricultural production will get much generous support from Brussels (MARD, 2004; Szabó et al., 2003).

In the Figure 4 the ecological network of the country is demonstrated.

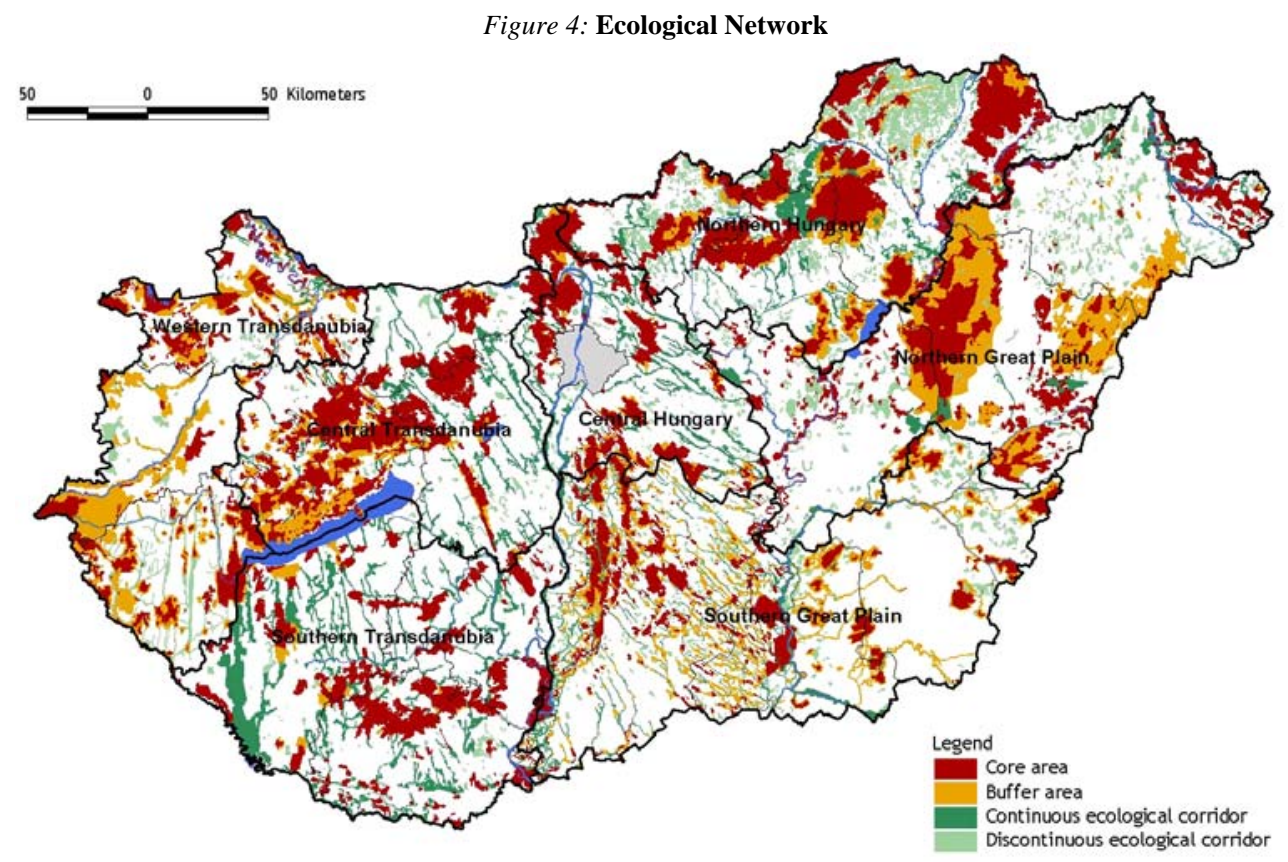

Source: Ministry of Environment and Water, Bureau for Nature Conservation 
We can see that Hungary is rich in ecological values and it ensures the preconditions of such programmes. A part of places with high ecological values coincides the areas with unfavourable agricultural endowments and underdeveloped microregions. We think so that the marginalisation preserves the non environmental-sound activities and hinders the development of multifunctional agriculture and this process can change only by joint utilisation of endogenous and exogenous resources and methods. Thus the successful programmes for agri-environmental protection and multifunctional land use can serve the moderation of negative effects of marginalisation or maybe the marginalisation process itself.

\section{CONCLUSIONS}

1) We aimed in our study to direct the attention to exact interpretation of the categories of marginalisation and multifunctional land use, considering that these concepts are relative new in Hungary. In the first place we understood the marginalisation in Hungary as the presence and increase of regional tensions which are hard to manage with ordinary tools and measures. Marginalisation has also an international dimension, thus elaboration of a system of its indices, or creating of a complex indicator requires a harmonised international co-operation.

2) In the nineties the marginalisation of the Hungarian agriculture and land use has made a considerable progress. In Hungary the process of marginalisation has prevailed together with a regional structural crisis in which the agriculture has played a decisive role.

3) The recognition of the advantages of multifunctional land use and the practice of multifunctional agriculture are only in an early stage in Hungary. Two years results of the National Agri-Environmental Programme are promising, however a change of paradigm is inevitable in thinking of farmers as well as central and local governmental bodies in the interest of successful utilisation of EU funds for the rural development.

\section{REFERENCES}

Ángyán, J.-Fésüs, I.-Podmaniczky, L.-Tar, F.-Vajnáné, M. A. (Eds.) (1999): Nemzeti Agrár-környezetvédelmi Program (National Agri-environmental Programme). FVM, Budapest

Balázs, K.-Szabó, G.-Podmaniczky, L. (2002): Agri-environmental Policy in Environmentally Fragile Areas in Hungary. In: Gatzweiler, F. W.-Judis, R.-Hagedorn, K. (Eds.): Sustainable Agriculture in Central and Eastern European Countries. Shaker Verlag, Achen, 191-194.

Baranyai, B. (ed.) (2001): A határmentiség kérdőjelei az Északkelet-Alföldön (Borderness Issues in the North-Eastern Part of the Plain.). MTA Regionális Kutatások Központja, Pécs

Brower, F.-Lowe, P. (1998): CAP and the Rural Environment in Transition: a Panorama of National Perspectives. Wageningen

Cahill, C. (2001): The Multifunctionality of Agriculture: What Does it Mean? Eurochoices, Spring

Enyedi, Gy. (1996): Regionális folyamatok Magyarországon az átmenet időszakában (Regional issues in Hungary in the transitional period). Budapest

Faluvégi, A. (2000): A magyar kistérségek fejlettségbeli különbségei (Differences among the micro-regions according to development). Területi Statisztika, 2000. július, 319-346.

Fehér, A. (2000): Halmozottan hátrányos térségeinkről (Our cumulative less favoured areas). Gazdálkodás, 44. 1. 68-79.

Fehér, A. (2001): Kísérlet a regionális gazdaságok teljesítményének és eredményeinek mérésére (An attempt for the measurement of performances and results of regional economies). Regio Partner Vidékfejlesztési Kutató és Tanácsadó Kft., Kompolt (Manuscript)

Harte, L.-O' Connell, J. (2003): How well do Agri-Environmental Payments conform With Multifunctionality. EuroChoices, Spring

Keszthelyi, Sz.-Kovács, G. (2002): A tesztüzemek 2001. évi gazdálkodásának eredményei (Farm accountancy results on year 2001). Agrárgazdasági Információk, 2. Agrárgazdasági Kutató és Informatikai Intézet (AKII), Budapest
Mulvany, P. (1999): „Cultivating our Futures”, the FAO/Netherlands Conference on the Multifunctional Character of Agriculture and Land. 12-17 September 1999, Maastricht, The Netherlands (Report by Patrick Mulvany, ITDG, for RAFI) http://www.ukabc.org/mfcal.htm

Popp, J. (2003): KAP-reform és a többfunkciós mezőgazdaság. Gazdálkodás, XLVIII. 4. 48-59.

Popp, J.-Potori, N.-Udovecz, G. (2004): A Közös Agrárpolitika alkalmazása Magyarországon. Agrárgazdasági Tanulmányok, 5. Agrárgazdasági Kutató és Informatikai Intézet, Budapest

Sarudi, Cs. (2003): Térség- és vidékfejlesztés. A magyar térgazdaság és az európai integráció. Agroinform Kiadó, Budapest, 1-307.

Szabó, G.-Fehér, A. (2003): Multifunctional Use of Land Marginalisation - Rural Development (Hungarian Experiences and Expectations) 13 Submitted to the EUROLAN meeting 24-27 April 2003 at Skiphelle, Norway

Szabó, G.-Fésüs, I.-Balázs, K.-Katonáné, K. J. (2003): A Nemzeti Agrár-környezetvédelmi Program pályázatainak elemzése (Analysis of the applications for the action programmes of National Agro-environmental Programme). Gazdálkodás, XLVII. 1. 26-39.

Szücs, I.-Tóthné, L. K.-Gábrielné, T. Gy. (2001): A kedvezőtlen adottságú területek EU-konform lehatárolása (EU conform circumsribe of less favoured areas). Gazdálkodás, XLV. 3. 6777.

Guidelines (2003): Guidelines for The Study at the National Level, QLK5-CT-2002-02346, Prepared by the EUROLAN participants at the meeting 24-27 April 2003 at Skiphelle, Norway

KSH (2003a): Központi Statisztikai Hivatal (Hungarian Central Statistical Office): Tájékoztató a kiemelten támogatott településekröl (Guide to the eminently supported settlements). Budapest

KSH (2003b): Központi Statisztikai Hivatal (Hungarian Central Statistical Office): A leghátrányosabb helyzetü kistérségek (Cumulative less favoured micro-regions). Budapest 
KSH (2003c): Központi Statisztikai Hivatal (Hungarian Central Statistical Office): A mezőgazdaság strukturális változásai a kilencvenes években (Structural changes in the agriculture in the nineties). Budapest

MARD (2004): Ministry for Agriculture and Rural Development: National Rural Development Plan for the EAGGF Guarantee Section Measures - Hungary (final version). Budapest, 19 July 2004
OECD (2001): Sustainable Development (Critical Issues). Paris OECD-UN DP (2002): Sustainable Development Strategies: A Resource Book. Organization for Economic Co-operation and Development, Paris and United Nations, New York

Official Journal (1999): Council Regulation (EC) No 1257/1999 of 17 May 1999 on support for rural development from the European Agricultural Guidance and Guarantee Fund (EAGGF) and amending and repealing certain Regulations. JL $160,26.6 .80-102$. 